\title{
Rechazando una religiosidad ilustrada. El desmantelamiento de las medidas impulsadas por Pablo de Olavide en las Nuevas Poblaciones de Sierra Morena y Andalucía
}

\author{
Francisco José Pérez-Schmid Fernández'; Adolfo Hamer-Flores²
}

Recibido: 30 de junio de 2020 / Aceptado: 22 de febrero de 2021 .

Resumen. El propósito de este artículo es analizar cómo tras el encarcelamiento y sentencia inquisitorial condenatoria de Pablo de Olavide, el modelo de religiosidad que había intentado establecer en las Nuevas Poblaciones de Sierra Morena y Andalucía experimentó una rápida transformación que lo llevó a asemejarse a cualquier otra localidad del entorno en pocos años. Este proceso tuvo no solo el impulso de las autoridades civiles y, sobre todo, eclesiásticas sino también la buena disposición y colaboración de los vecinos de estas nuevas colonias que, en muchos casos, no compartieron ni entendieron la religiosidad que Olavide trató de impulsar entre ellos.

Palabras clave: Nuevas Poblaciones de Sierra Morena y Andalucía; religiosidad popular; Pablo de Olavide; Inquisición; siglo XVIII.

\section{[en] Rejecting a religiousness of the Enlightenment. The dismantling of the} measures promoted by Pablo de Olavide in the New Settlements of Sierra Morena and Andalusia

\begin{abstract}
The purpose of this article is to analyze how, after imprisonment and condemnation of Pablo de Olavide, the model of religiosity that he had tried to establish in the New Settlements of Sierra Morena and Andalusia underwent a rapid transformation that led him to resemble any other location of the surroundings in a few years. This process had not only the impulse of the civil and, above all, ecclesiastical authorities but also the willingness and collaboration of the residents of these new colonies that, in many cases, did not share or understand the religiosity that Olavide tried to promote among them.

Keywords: New Settlements of Sierra Morena and Andalusia; popular religiosity; Pablo de Olavide; Inquisition; $18^{\text {th }}$ century.
\end{abstract}

Sumario. Introducción. La Iglesia impulsa su presencia en las Nuevas Poblaciones. La autoridad diocesana y sus iniciativas. Vigilar las desviaciones: el Santo Oficio. Combatiendo una "religiosidad ilustrada". De las iglesias vacías a la profusión de altares y ornamentos. Las pláticas e iniciativas de fray Diego José de Cádiz. Más allá de la Inmaculada Concepción: los colonos manifiestan su fe. Conclusiones. Bibliografía.

1 Grupo de investigación HUM155 (Universidad de Jaén)

Email: fjperezfdez@telefonica.net

ORCID: https://orcid.org/0000-0002-9671-5953

2 Universidad Loyola Andalucía

Email: ahamer@uloyola.es

ORCID: https://orcid.org/0000-0001-5216-5470 
Cómo citar: Pérez-Schmid Fernández, F. J.; Hamer-Flores, A. (2021). Rechazando una religiosidad ilustrada. El desmantelamiento de las medidas impulsadas por Pablo de Olavide en las Nuevas Poblaciones de Sierra Morena y Andalucía, en Cuadernos de Historia Moderna 46.1, 261-283.

\section{Introducción}

La figura del limeño Pablo de Olavide y Jáuregui (1725-1803) ha sido objeto, ya desde el siglo XIX, de numerosos trabajos de investigación que han tratado de arrojar luz sobre su trayectoria biográfica ${ }^{3}$ o acerca de cuestiones relevantes como, por ejemplo, su pensamiento en materia agraria ${ }^{4}$, su producción escrita ${ }^{5}$, su plan de reforma universitaria ${ }^{6}$ o el proceso inquisitorial ${ }^{7}$ que lo condenó como "hereje formal y miembro podrido de la religión" en 1778 tras dos años de prisión secreta. No obstante, ello no ha impedido que en otras muchas cuestiones casi no conozcamos nada más allá de unas ideas generales. Este es el caso de la influencia que este tuvo en el modo de vivir y entender la religiosidad entre los habitantes de las Nuevas Poblaciones de Sierra Morena y Andalucía, pues como su superintendente y encargado de ponerlas en marcha a partir de 1767 tuvo ocasión de incidir notablemente en este aspecto. Un hecho facilitado, además, por la propia naturaleza de estas nuevas colonias, concebidas como un ensayo gubernamental de sociedad agraria modelo. Entre las muchas innovaciones que se introdujeron, las relacionadas con la religiosidad popular no estuvieron ausentes $\mathrm{y}$, por razones obvias, pronto generaron problemas con las autoridades eclesiásticas y provocarían, desde el inicio, un tímido rechazo o resistencia en parte de la población.

\footnotetext{
No pretendemos aquí ofrecer una relación exhaustiva de las biografías dedicadas a Olavide, de ahí que solo señalemos las más relevantes: Lavalle, J.A.: Don Pablo de Olavide. Apuntes sobre su vida y sus obras, Lima, Imprenta Americana, 1859; Alcázar Molina, C.: Los hombres del reinado de Carlos III. Pablo de Olavide (el colonizador de Sierra Morena), Madrid, Editorial Voluntad, 1927; y Défourneaux, M.: Pablo de Olavide ou l'afrancesado (1725-1803), Paris, Presses Universitaires de France, 1959.

4 Perdices Blas, L.: La agricultura de la segunda mitad del siglo XVIII en la obra y empresa colonizadora de Pablo de Olavide, Madrid, Editorial Complutense, 1988; Perdices Blas, L.: "La agricultura en la empresa colonizadora de Pablo de Olavide", en: Estructuras agrarias y reformismo ilustrado en la España del siglo XVIII, Madrid, Ministerio de Agricultura, Alimentación y Medio Ambiente, 1989, pp. 585-589; Perdices Blas, L.: Pablo de Olavide (1725-1803). El Ilustrado, Madrid, Editorial Complutense, 1992; y Pérez Fernández, F.J.: "Olavide, del pensamiento teórico al práctico: una aproximación al asentamiento de colonos y a los propietarios en las Nuevas Poblaciones", Tiempos Modernos. Revista Electrónica de Historia Moderna, 37 (2018), pp. 299-319.

5 Destacan los numerosos trabajos de María José Alonso Seoane, de los que no ofreceremos un listado por ser muy abundantes y tratar cuestiones variadas.

6 Castellano Castellano, J.L.: "Las nuevas ideas pedagógicas y la reforma de Olavide", Chronica Nova. Revista de Historia Moderna de la Universidad de Granada, 12 (1981), pp. 67-89; Fernández Sanz, A.: "La reforma universitaria del ilustrado Pablo de Olavide", Anales del Seminario de Historia de la Filosofia, Extra ${ }^{\circ}$ 1(1996), pp. 327-345; Marchena Fernández, J.: Pablo de Olavide, el espacio de la Ilustración y la reforma universitaria. Vida y obra de un ilustrado americano y español, Sevilla, Universidad Pablo de Olavide, 2000; y Aguilar Piñal, F.: "La reforma universitaria de Olavide", Cuadernos Dieciochistas, 4 (2003), pp. 31-46.

7 Gómez Urdáñez, J.L.: "El caso Olavide: el poder absoluto de Carlos III al descubierto", en Muñoz Machado, S. (ed.): Los grandes procesos de la Historia de España, Barcelona, Crítica, 2002, pp. 308-334; Gómez Urdáñez, J.L.: "Con la venia de Carlos III. El castigo 'ejemplar' de Olavide, consecuencia de la venganza de Grimaldi contra el conde de Aranda", Vegueta: Anuario de la Facultad de Geografia e Historia, 15 (2015), pp. 373-400; y García Cano, M.I.: "El proceso inquisitorial de Pablo de Olavide en el Siglo de las Luces", Codex. Boletín del Instituto Español de Estudios Histórico-Jurídicos, 8 (2018), pp. 57-92.
} 
El objetivo fundamental de este trabajo, por tanto, consistirá en analizar esa mencionada resistencia a los cambios introducidos por Olavide en el modo de vivir y manifestar la religiosidad en las Nuevas Poblaciones de Sierra Morena y Andalucía. Para ello nos centraremos en lo acontecido en los años inmediatamente posteriores a su salida definitiva de esas colonias con destino a Madrid (12 de noviembre de 1775), su detención por parte del Santo Oficio (14 de noviembre de 1776) y su condena inquisitorial (24 de noviembre de 1778$)^{8}$. De este modo estaremos en disposición de comprobar si es posible validar nuestra hipótesis de que la marcha del superintendente facilitó un impulso por parte del sector eclesiástico para borrar todas esas innovaciones, a la par que su influencia se hacía más presente en la sociedad neopoblacional, así como la existencia de una eclosión en el ámbito popular de devociones y prácticas hasta entonces limitadas.

En lo que respecta a las fuentes primarias empleadas, haremos uso de documentación conservada tanto en archivos estatales (Archivo General de Simancas y Archivo Histórico Nacional) como en otros locales, provinciales y de distrito (con fondos de alguna o algunas de las nuevas colonias). Todo ello con el propósito de disponer de un conjunto de datos lo suficientemente amplio y con la relevancia necesaria como para alcanzar conclusiones válidas. Información que, debidamente contextualizada con lo aportado hasta ahora por la comunidad científica, facilitará un acercamiento al tema mediante tres grandes pilares: el modo en el que la Iglesia refuerza su presencia y autoridad, cómo se desmantelaron los principales rasgos de la religiosidad impulsada por Olavide y la eclosión a partir de 1776 de una religiosidad popular hasta entonces contenida y reorientada hacia cultos muy concretos.

\section{La iglesia impulsa su presencia en las Nuevas Poblaciones}

El Fuero de Población de 1767, disposición normativa que se erigió en norma suprema en esta nueva jurisdicción ${ }^{9}$, incluyó en su articulado algunas cuestiones relacionadas con la Iglesia y el culto; aunque muy mediatizadas por el regalismo de su redactor, el fiscal del Consejo de Castilla Pedro Rodríguez de Campomanes. Entre ellas podemos señalar que los párrocos serían designados por el monarca y pagados por la Superintendencia de Nuevas Poblaciones (artículos 14, 18 y 20), que la Real Hacienda construiría las iglesias y las casas para los párrocos (artículo 15) y la prohibición de establecer conventos, comunidades, hospicios, entre otras instituciones de este tipo, dando preferencia a los párrocos diocesanos (artículo 77). Aún más, el artículo 52 fue fundamental en los inicios, pues confería plena autoridad al superintendente -intendente a partir de 1784-; un hecho que, en la práctica, se tradujo en un claro control de este cargo y del Consejo de Castilla en cuestiones de culto ${ }^{10}$.

Un detallado análisis de los principales rasgos de esta religiosidad en el periodo comprendido entre 1767 y 1776, así como de los focos de resistencia que surgieron en su aplicación puede consultarse en Hamer Flores, A. y Pérez Fernández, F.J.: "Una fe a la luz de la Ilustración. El frustrado modelo de religiosidad de Pablo de Olavide para las Nuevas Poblaciones de Sierra Morena y Andalucía (1767-1776)", Hispania Sacra, 147 (2021), en prensa.

9 Su denominación completa era: Real Cedula de su majestad, y señores de su Consejo, que contiene la instrucción y fuero de población que se debe observar en las que se formen de nuevo en la Sierra Morena con naturales y extranjeros católicos, Madrid, Imprenta de Antonio Sanz, 1767.

10 Pérez Fernández, F.J. y Hamer Flores, A.: "Ilustración y religiosidad popular en las Nuevas Poblaciones de 
Como cabía esperar, una participación tan amplia de la autoridad civil en cuestiones de ámbito religioso no tardó en dar lugar a diferentes protestas por parte de las autoridades eclesiásticas de las propias colonias. De ahí que, tras la visita de inspección realizada en la primavera y verano de 1769 por Pedro José Pérez Valiente, las limitaciones impuestas a Olavide fueran incrementándose. El Consejo de Castilla le remitió una instrucción fechada el 6 de julio de 1770 en la que se recogían una serie de medidas de obligado cumplimiento, entre las que también se incluyeron algunas que afectaban a cuestiones religiosas (artículos 45 a 49). En ellas observamos una reorganización en la gestión eclesiástica, al disponer desde el Consejo que la administración de las aldeas y casas dispersas debía ser para la diócesis donde se encontraba la capital de la feligresía ${ }^{11}$. Esto significó de facto la eliminación de problemas competenciales con la Vicaría de Beas o el Arciprestazgo de Toledo y la centralización del poder eclesiástico de las colonias de Sierra Morena en el obispo de Jaén $^{12}$, y en el caso de las situadas en Andalucía en el obispo de Córdoba (La Carlota, San Sebastián de los Ballesteros y Fuente Palmera) y el arzobispo de Sevilla (La Luisiana). Expresamente se indicaba cómo el superintendente debía remitir a dichas diócesis el estado de los puntos de población, sus aldeas y casas dispersas, junto con las distancias y el número de familias, lo que implicaba el inicio de una mayor tutorización por parte de los obispos de los trabajos realizados en las colonias. Debía informar también del número de iglesias y capillas, del de ministros, de los libros y reglas, de las alhajas y enseres para el culto, etc., así como de todo lo necesario para formar un reglamento para los capellanes y prelados foráneos que debieran nombrarse. Incluso se concedía potestad a los eclesiásticos para que pudieran encargar la construcción de ermitas, capillas u oratorios públicos para atender a los vecinos que vivían en casas dispersas, y de esta manera poder celebrar misa los días festivos, debiendo el superintendente acordar con los prelados todos estos aspectos ${ }^{13}$. Por lo tanto, tres años después de la redacción del Fuero, el poder de Olavide en materia religiosa se redujo sustancialmente, entrando los obispos a controlar directamente dicha labor. No obstante, el hecho de que finalmente las diócesis no se hicieran cargo de los gastos eclesiásticos y de pensiones que se especificaban en el artículo 33 de la instrucción, facilitó el que la Superintendencia continuara costeando dichos gastos y manteniendo por ello cierto margen de influencia ${ }^{14}$.

Sierra Morena y Andalucía: las cofradías que Olavide no quiso", Vegueta. Anuario de la Facultad de Geografía e Historia, 19 (2019), pp. 669-670.

11 No se produjo, ciertamente, una modificación jurisdiccional, pues esta solo podía ser realizada por la Iglesia, pero al facilitar que el clero pudiera ejercer sus funciones dentro de cada feligresía sin limitaciones (con autorización de distintas diócesis en caso de que su territorio se extendiera por más de una) se evitaron las disputas de los primeros años.

12 La orden de Carlos III quedó reflejada en los libros de la parroquia de Montizón, indicando cómo en 1770 todas las iglesias y capillas de las Nuevas Poblaciones de Sierra Morena quedaban dentro de la jurisdicción del Obispado de Jaén. En Archivo Parroquial de Montizón, Jaén (APM), Libro de visitas de la iglesia de Montizón y ermita de Nazaret.

13 Alcázar Molina, C.: Las colonias alemanas de Sierra Morena (Notas y documentos pasa su historia), Madrid, Universidad de Murcia, 1930, pp. 157-158.

14 Palacio Atard, V.: Las «Nuevas Poblaciones» andaluzas de Carlos III. Los españoles de la ilustración, Córdoba, Monte de Piedad y Caja de Ahorros de Córdoba, 1989, pp. 54-55. 


\section{La autoridad diocesana y sus iniciativas}

La implicación de obispos y arzobispos en la supervisión de las colonias que se encontraban dentro de su jurisdicción fue muy limitada durante los años en los que Pablo de Olavide ocupó la Superintendencia. Un control ejercido básicamente mediante la correspondencia que se intercambiaban con sus gobernantes y sacerdotes, aunque sin entrar a cuestionar, por lo general, los aspectos vinculados al modelo de religiosidad que Olavide impulsaba en ellas. A grandes rasgos, este último compartía con la Iglesia el rechazo de todos los delitos y faltas que atentaran contra la moral vigente, contra las buenas costumbres o que pudieran alterar la ortodoxia cristiana. Además, no puede obviarse que las propias autoridades diocesanas no veían con mucho agrado algunas de las manifestaciones populares de devoción y culto entonces existentes, bien por verlas irrespetuosas o bien por excesiva autonomía, de ahí que consideremos que pudieran compartir algunas de las medidas del limeño. Un ejemplo de ello lo tenemos en las colonias situadas en la diócesis de Córdoba, donde el obispo insistía en 1792 en la prohibición de instalar en los templos nuevos altares de madera, permitiéndose solo los de piedra o estuco para evitar incendios ${ }^{15}$. Si en ese momento los altares no eran muchos, en los primeros años, cuando apenas existían uno o dos por templo, todas las iglesias y capillas se ajustaban a este tipo de normas. Es probable que esto explique el que en las Nuevas Poblaciones de Andalucía no se produzca ninguna visita de inspección o pastoral antes de 1780, y que en esta el obispo quedase muy satisfecho con la "decencia y ornato" de las iglesias, habiendo recibido solo peticiones de ampliar el número de capillas y capellanes, así como de establecer pila bautismal y cementerio en la colonia de San Sebastián de los Ballesteros, punto este último al que accedió inmediatamente ${ }^{16}$.

Las Nuevas Poblaciones de Sierra Morena, en cambio, sí acogieron hasta tres visitas pastorales durante el gobierno de Olavide. Todo apunta a que de las dos primeras no se derivó ninguna queja por parte del obispado de Jaén, una situación que se modifica a partir de la tercera, realizada ya en un contexto enrarecido, con el superintendente residiendo en Madrid y pocos meses antes de que fuera encarcelado. Fray Benito Marín realizó la primera visita en 1768, aunque su fallecimiento poco después impidió que se levantase el correspondiente informe. Su sucesor, Antonio Gómez de la Torre, las visitó en dos ocasiones: en la primera visita, realizada en 1773 , no señaló nada fuera de la normalidad ${ }^{17}$ tras revisar y observar edificios, or-

15 Carta del capellán mayor de La Carlota al obispo de Córdoba, La Carlota, 18 de febrero de 1792, Archivo General del Obispado de Córdoba (AGOC), Despachos Ordinarios, caja 7117, atado 1, exp. 22, doc. 2.

16 Carta del obispo de Córdoba a Miguel de Múzquiz, Cabra, 8 de septiembre de 1781, Archivo General de Simancas (AGS), Secretaría y Superintendencia de Hacienda, leg. 499, doc. 487.

17 Algún investigador ha manifestado que, desde los primeros momentos de la colonización, tanto los obispos como los enviados episcopales procuraron estar muy atentos para garantizar en ellas que la organización religiosa católica se ajustara a la existente en cualquier otro lugar, una afirmación que, sin ser completamente errónea, no se ajusta del todo a la realidad. Sin duda, ese celo episcopal observado en la etapa posterior al encarcelamiento de Olavide facilita el suponer que la etapa previa también tuvo los mismos rasgos. En este sentido, Fernández García, sin mencionar datos de fechas anteriores, emplea como única evidencia para sostener esta hipótesis las indicaciones que Gómez de la Torre dio en su visita pastoral de 1773 acerca de la necesidad de que no se usasen abreviaturas poco frecuentes en las partidas de los libros sacramentales y que todas las que habían sido extendidas en los primeros años en latín debían traducirse al español; unas indicaciones orientadas más a corregir una mala praxis por parte del propio sector eclesiástico que a reivindicar su autoridad en la sociedad neopoblacional. Fernández García, J.: “Aspectos particulares y decisivos de la Iglesia en las Nuevas Poblaciones”, en R. Váz- 
namentos, cultos, administración de sacramentos, feligreses, etc.; incluso no dudó en abrir su informe de visita con una alabanza a Carlos III $^{18}$. Tres años más tarde, su segunda visita evidenciará en el obispo una actitud diferente. Poco antes de ponerse en marcha hacia las colonias, avisa a Olavide de que convenía "dar providencia y arreglo en muchas cosas que lo piden para la uniformidad de aquello con el resto del obispado", indicándole que el capellán mayor de La Carolina también le escribirá sobre ello para ir adelantando en la materia ${ }^{19}$. Asistimos, pues, al inicio de una serie de exigencias que venían a poner punto final a cuestiones consentidas durante años ${ }^{20}$. Ciertamente fueron bastantes, como lo demuestra el listado que en junio de 1776 remitió al capellán mayor de La Carolina, donde le indica que era necesario "que se erijan altares colaterales en esa parroquial [de La Carolina], se coloquen imágenes, se adornen las iglesias decentemente, se renueven los sagrados ornamentos, se construyan las iglesias de las Navas y Miranda y se echen vidrieras en las que no las tienen" 21 , pero, a modo de ejemplo, nos centraremos ahora solo en las más relevantes: la modificación de la indumentaria femenina para asistir a la iglesia, los cambios en el ritual de entierro de los colonos y el establecimiento de cofradías y hermandades.

Gómez de la Torre se mostraba muy interesado en que todas las mujeres, tanto las extranjeras como las españolas, acudieran a la iglesia con traje español por considerarlo más acomodado al pudor. Una decisión que entraba en directa colisión con la exigencia de Olavide para que no llevasen prendas que les cubriesen la cabeza y los hombros. Con un superintendente preocupado por las denuncias contra su persona que se movían en el Santo Oficio, esta petición no encontró casi resistencia. En ese mismo año de 1776 nos consta que las españolas ya podían ir por las calles de La Carolina y a su iglesia con cabeza, cuello y pecho cubiertos sin que se les apercibiera por ello ${ }^{22}$. Es más, un año después únicamente las alemanas acudían todavía sin las prendas habituales en España, llevando solo una pequeña cofia al estilo de sus lugares de origen ${ }^{23}$; lo que no impedía que el capellán mayor Lanes y Duval buscase la colaboración del subdelegado de la Superintendencia para que también estas vistiesen como aquellas ${ }^{24}$.

quez Lesmes y S. Villas Tinoco (coords.): Actas del VI Congreso Histórico sobre Nuevas Poblaciones, Córdoba, Junta de Andalucía, 1994, p. 107.

18 Martínez Rojas, F.J.: "Organización eclesiástica y atención pastoral en las Nuevas Poblaciones de Sierra Morena”, en F. J. Pérez-Schmid Fernández, F.J. y Rodrigo Sanjuán, P. (coords.): 250 aniversario de la promulgación del Fuero de las Nuevas Poblaciones, Jaén, Fundación Caja Rural de Jaén, 2018, p. 62.

19 Carta del obispo de Jaén a Pablo de Olavide, Jaén, 16 de mayo de 1776, Archivo Histórico Nacional (AHN), Inquisición, leg. 3603, s.f.

20 Unas peticiones que se vieron respaldadas, más aún si cabe, cuando el rey solicitó el 25 de septiembre de 1777 al obispo de Jaén, conformándose con el dictamen del Consejo de Castilla, que realizara una visita a las colonias de Sierra Morena para que "ordene y disponga todo lo concerniente al culto y pasto espiritual”, y que este efectuó en el mes de noviembre (Carta de Miguel de Múzquiz a Miguel de Ondeano, San Ildefonso, 25 de septiembre de 1777, AHN, Fondos Contemporáneos, Gobernación, leg. 334, exp. 2). Citado en Alcázar Molina, op. cit. (nota 13), p. 60.

21 Carta de Juan Lanes y Duval a Miguel de Múzquiz, La Carolina, 16 de mayo de 1777, AGS, Secretaría y Superintendencia de Hacienda, leg. 499, doc. 62.

22 Declaración de Juan Adam Spies, 1777, AHN, Inquisición, leg. 1866, pieza 3, testigo 100.

23 Declaración de Jerónimo de Gillenea, 1777, AHN, Inquisición, leg. 1866, pieza 3, testigo 101.

24 Carta de Juan Lanes y Duval a Miguel de Ondeano, La Carolina, 9 de febrero de 1777 y carta de Miguel de Ondeano a Juan Lanes y Duval, La Carolina, 15 de febrero de 1777, AGS, Secretaría y Superintendencia de Hacienda, leg. 499, docs. 62 y 64. 
En lo que se refiere a los entierros de los colonos, el superintendente no era partidario de que, una vez realizados los oficios dentro de las iglesias, se conformasen grandes cortejos fúnebres en los que los eclesiásticos acompañaran a los féretros portando la cruz parroquial hasta el cementerio. Del mismo modo, en La Carolina había prohibido que se tocasen las campanas en casos de entierro, tanto para evitar las molestias que le causaban, al estar muy próximas a la ventana del despacho donde trabajaba, como para evitar el desánimo y las deserciones de los colonos por la elevada mortalidad de los primeros años. Unas limitaciones que, tras su marcha, se encontraban ya completamente superadas en $1777^{25}$.

Por último, en lo que concierne al establecimiento de cofradías, el obispo de Jaén solicitó en 1776, tanto a Olavide como a su subdelegado Miguel de Ondeano, que se creasen algunas dedicadas al Santísimo Sacramento y a las Ánimas Benditas. La situación del superintendente en esos momentos, como ya hemos manifestado, era lo suficientemente delicada como para que en esta ocasión decidiera ceder ante las demandas, derivando al Consejo de Castilla esta petición. Al año siguiente, las colonias de Sierra Morena se polarizaron en torno a dos posturas. De un lado, el sector eclesiástico local, apoyado por las autoridades diocesanas, insistía en la puesta en marcha de esas cofradías de manera inmediata; mientras que, de otro, el subdelegado Miguel de Ondeano afirmaba no poder tomar decisiones en este sentido mientras que el Consejo de Castilla no se pronunciara. Debido a que, en la práctica, se impuso el criterio de las autoridades civiles, el sector eclesiástico no dudó en fomentar la organización oficiosa de esas agrupaciones. El conflicto no tardó en llegar y el intento de crear cofradías en Santa Elena, Arquillos o Navas de Tolosa, llevó a la prohibición de sus actividades por la Subdelegación, elevando consulta al Consejo de Castilla. No obstante, gracias al apoyo del obispado y a la labor del capellán mayor, ese largo pleito se resolvió con la autorización por el citado Consejo para que se instalasen cofradías dedicadas al Santísimo Sacramento y a las Ánimas Benditas en Sierra Morena. En las Nuevas Poblaciones de Andalucía, sin que mediase, al parecer, resistencia en las autoridades civiles, la creación de hermandades tuvo lugar a partir de la primavera de 1777 cuando se establecieron las dos primeras, dedicadas a las Ánimas y a Nuestra Señora del Rosario en La Carlota ${ }^{26}$.

Alcanzados, o en marcha, la mayor parte de los objetivos que se propusieron las diócesis para mostrar su autoridad en las nuevas colonias y garantizar el culto y las prácticas religiosas, los obispos siguieron ejerciendo una estrecha supervisión en los años siguientes; aunque algunas de sus propuestas también se frustraron. Este fue el caso, por ejemplo, de la petición realizada por el obispo de Jaén en marzo de 1777 para que los sacristanes no se mezclasen en asuntos civiles sirviendo además como maestros, notarios y fieles de fechos. Una disposición que, comunicada por Lanes y Duval al subdelegado de Sierra Morena, encontró una rápida acogida en Miguel de Ondeano, que dispuso que a partir de ese momento el salario asignado para estas funciones se dividiría entre los dos individuos que a partir de entonces las realizaran. Un tercio quedaría para los sacristanes y los dos tercios restantes para los que desempeñasen el empleo de maestro y fiel de fechos. El rey se conformó provisionalmente con esta decisión, pero ordenó que el asunto pasase al Consejo de Castilla para su

25 Declaraciones de Lorenzo Felder y Jerónimo de Guillenea, 1777, AHN, Inquisición, leg. 1866, pieza 3, testigos 99 y 101.

26 Pérez Fernández y Hamer Flores, op. cit. (nota 10), p. 671-674. 
estudio. Además, como era de esperar, los perjudicados por esta reducción de salario no tardaron en elevar sus instancias al monarca argumentando la irregularidad de la medida por no respetar el contenido de sus nombramientos y por dificultar su subsistencia esa considerable reducción salarial ${ }^{27}$. Desconocemos si tuvo lugar por disposición del Consejo o como resolución a favor de los segundos, pero lo cierto es que no muchos años después de esta medida las funciones de maestro de primeras letras, sacristán y fiel de fechos volvían a ser desempeñadas por la misma persona en la mayor parte de las feligresías ${ }^{28}$, realidad que se extendió hasta $1835^{29}$.

En Sierra Morena, aunque la primera visita ad limina que realizó en su territorio el obispo Agustín Rubín de Ceballos ${ }^{30}$, que había sucedido en septiembre de 1780 a Gómez de la Torre, fallecido el año anterior, tuvo que esperar hasta 1789, este no dudó en realizar algunas visitas a las parroquias de los pueblos en los años anteriores. Este fue el caso de la feligresía de Montizón, en la que Rubín de Ceballos se personó el 7 de enero de 1782, realizando una detallada inspección de los libros sacramentales, de la iglesia y ermitas y de los materiales y ornamentos para el culto, a la que siguió una extensa relación de indicaciones sobre obras a realizar y acerca del culto y las costumbres de sus vecinos ${ }^{31}$. Del contenido de estas se colige su interés en que el párroco y los padres de familia cuiden de que sus hijas no tengan frecuente trato con jóvenes con la excusa de haber contraído esponsales de futuro, se queja de la existencia de "conversaciones e inmodestias" dentro de la iglesia que no deberían producirse, así como de bailes y comportamientos inadecuados en día de Navidad y de Santos Inocentes, y anima a que se asista a misa los días festivos y a que se cuide la instrucción religiosa que el maestro ofrece en la escuela ${ }^{32}$. Todo ello nos permite concluir que la marcha de Olavide dio paso a una presencia mucho más activa de las autoridades diocesanas en las nuevas colonias, vigilando con más celo aspectos que antes recaían mayoritariamente en el clero local y ante cuya relajación solo se actuaba con timidez.

Un último ejemplo de la reafirmación del poder eclesiástico en las colonias lo encontramos a mediados de los años ochenta cuando, tras la finalización de las obras del paso de Despeñaperros en 1783, se decidió colocar un monolito que marcaba los límites entre el Obispado de Jaén y el Arzobispado de Toledo, conocido como la Cara de Dios $^{33}$. Un hito religioso para conferir protección a los usuarios del nue-

$27 \quad$ AGS, Secretaría y Superintendencia de Hacienda, leg. 499, doc. 161.

28 En una carta remitida, el 13 de junio de 1781, por el subdelegado Ondeano al comandante civil de Santa Elena se confirma que estas tres ocupaciones volvían a estar unidas en la misma persona; es más, se regulaba hasta el tiempo que debía dedicarse a cada una de ellas. En Archivo Histórico Municipal de Aldeaquemada, Jaén (AHMA), caja 278.

29 En 1833 el intendente Pedro Polo de Alcocer, al realizar una minuciosa descripción de la organización administrativa y principales hitos históricos de las Nuevas Poblaciones, indica que Olavide estableció en cada punto de población un sacristán que fuese a la vez maestro y fiel de fechos, no especificando en ningún momento que se hubieran producido cambios en estas funciones. AHN, Fondos Contemporáneos, Gobernación, leg. 2738, exp. 16.

30 Agustín Rubín de Ceballos fue nombrado obispo de Jaén el 18 de septiembre de 1780 e inquisidor general el 17 de febrero de 1784. Se le condecoró con la Orden de Carlos III. Falleció en Madrid el 8 de febrero de 1793. Nicás Moreno, A.: Heráldica y genealogía de los obispos de la Diócesis de Jaén, Jaén, Instituto de Estudios Giennenses, 1999, p. 149.

31 También nos consta que en el verano de ese mismo año hizo sendas visitas a las parroquias de las colonias de La Carolina y Navas de Tolosa.

32 Diligencias de la visita en 1782 del obispo Agustín Rubín de Ceballos, APM, Libro 1 de Bautismos.

33 En el antiguo camino del Puerto del Rey también había colocada una Cara de Dios, aunque su presencia databa 
vo camino ${ }^{34}$ y que supuso una verdadera novedad dentro de la jurisdicción de las Nuevas Poblaciones, pues hasta entonces este espacio había estado reservado para los símbolos relacionados con la Corona, como territorio realengo que era. Tanto es así que estableció desde sus primeros momentos un cuidadoso programa propagandístico e iconográfico para publicitarse y difundir los éxitos de este proyecto de colonización ${ }^{35}$.

\section{Vigilar las desviaciones: el Santo Oficio}

El hecho de que la jurisdicción diocesana estuviera mediatizada por el patronato del monarca, que sufragaba en las nuevas colonias tanto los gastos de culto como los salarios de los eclesiásticos, hizo que el cauce para gestionar la práctica totalidad de los asuntos religiosos fuesen los capellanes mayores establecidos en cada una de sus dos capitales. Tanto es así que no solo estuvieron ausentes en ellas los conventos y las órdenes regulares, por expresa prohibición del Fuero, sino que empleos habituales en otros lugares, como los familiares del Santo Oficio, tampoco tuvieron representación en sus primeros años de existencia. Estos últimos habrían ocasionado no pocos quebraderos de cabeza a Olavide, de ahí que, si en algún momento se le llegó a plantear su implantación, algo de lo que carecemos de datos, sin duda, la esquivaría por haber dificultado el desarrollo de su particular modo de entender cuestiones como el ocio ${ }^{36}$ o la religiosidad popular.

No puede extrañarnos, por tanto, el que la Inquisición hiciera acto de presencia en las Nuevas Poblaciones solo por asuntos graves y concretos (los cuales escapaban de las competencias de la secretaría del Despacho de Hacienda y a las del Consejo de Castilla, y no podían encomendarse sin más a los capellanes mayores), teniendo incluso dificultades para tomar declaración en ellas a sus vecinos por la ausencia de esa red local de familiares del Santo Oficio que mencionábamos antes. Las denuncias contra Olavide hicieron que desde 1769 se empezaran a recopilar testimonios, con mucha discreción, en las nuevas colonias, algo que se incrementó notablemente una vez que se le encarceló en noviembre de 1776 y que ya era innecesaria tanta caute$\mathrm{la}^{37}$. Pero no fue este el único proceso que se instruyó en esos años, pues nos constan algunos otros por cuestiones heréticas y de bigamia $^{38}$.

de mucho antes de establecerse las Nuevas Poblaciones. Pérez-Schmid Fernández, F. J.: Historia de la colonia de Miranda del Rey y la aldea de Magaña (1767-2017), Jaén, Ayuntamiento de Santa Elena, 2017, p. 8.

34 En la parte que mira hacia el límite del Obispado de Jaén el relieve de la Santa Faz se acompaña con el siguiente texto epigráfico: «Verdadero retrato de la Santa Cara de Dios de Jaén siendo el Excelentísimo Señor Don Agustín Rubín de Ceballos su obispo [ilegible]»; y mirando hacía el Arzobispado de Toledo la Virgen del Sagrario se sitúa sobre este texto: «Nuestra Señora del Sagrario de Toledo siendo el Excelentísimo Señor Don Francisco Antonio Lorenzana su Arzobispo Prelado». Transcripciones realizadas directamente a partir del hito, que todavía se encuentra en el lugar donde se ubicó.

35 Para profundizar sobre los elementos de la propaganda borbónica en la Intendencia de Nuevas Poblaciones véase Hamer Flores, A. y Pérez Fernández, F. J.: "Visualizando el poder real. Toponimia y heráldica en las Nuevas Poblaciones de Sierra Morena y Andalucía”, Investigaciones Históricas. Época Moderna y Contemporánea, 39 (2019), pp. 257-292.

36 Pérez Fernández, F.J. y Hamer Flores, A.: "Reformar las costumbres. Pablo de Olavide y su modelo de ocio para las Nuevas Poblaciones de Sierra Morena y Andalucía (1767-1776)”, Cuadernos Dieciochistas, 21 (2020), pp, 519-547.

37 La mayor parte del voluminoso proceso inquisitorial de Pablo de Olavide se conserva en el fondo de Inquisición del Archivo Histórico Nacional bajo la signatura legajo 1866.

38 Proceso seguido en 1768 por el Tribunal de Córdoba contra el colono alemán Juan Lang por bigamia. AHN, In- 
En cualquier caso, esa presencia nunca dejó de ser puntual, de ahí que para procesos que implicaban periodos prolongados las autoridades diocesanas y la Inquisición optaran por delegar estos cometidos en los capellanes mayores. Esto fue lo que ocurrió en los primeros años de la colonización con los colonos protestantes que se detectaron en las nuevas colonias, al encomendar el Tribunal de la Inquisición de Córdoba la responsabilidad de examinarlos, expulsarlos o de prepararlos para las abjuraciones al capellán mayor de La Carlota, algo que también se hizo extensivo al de La Carolina ${ }^{39}$. No obstante, el encarcelamiento de Olavide a fines de 1776, que durante dos años hizo que fuera "borrado del mundo de los vivos" 40 , implicó no solo que las Nuevas Poblaciones se vieran frecuentadas por representantes del Santo Oficio para realizar incautaciones y tomar declaraciones sino también la instalación, en 1777, por vez primera, de un alguacil mayor del Santo Oficio en La Carolina.

Los detentadores de esta dignidad poseían autoridad para ejecutar las órdenes relativas a los reos del Santo Oficio dictadas por los inquisidores, estando sus actuaciones protegidas bajo multa o pena de excomunión mayor. Además, las autoridades y justicias debían guardarles los honores, exenciones y privilegios debidos por el cargo $^{41}$. Por su parte, los aspirantes debían ser personas de alta condición social, ya que los nombramientos estaban precedidos de informes de limpieza de sangre del adquiriente y de su mujer. En ocasiones era tal su relevancia que se darían casos en los que su posesión tuvo más un carácter honorífico y representativo, creándose el cargo de teniente de alguacil para evitar que el alguacil mayor tuviera que participar directamente en las funciones ejecutivas ${ }^{42}$.

Este honor recayó, en el caso que aquí analizamos, en Alonso Mesía Valdivia, al que se le expidió el correspondiente título el 26 de abril de $1777^{43}$. Natural de Andújar, había sido el único hijo del matrimonio conformado por Bartolomé Mesía y Ana de Valdivia. Acumulaba este por entonces una gran cantidad de cargos y distinciones: ex colegial de Sacromonte de Granada, bachiller en Sagrados Cánones y Jurisprudencia Civil, ex capitán del regimiento de milicias de Jaén, ex alcalde de hidalgos de la Santa Hermandad de Andújar, propietario y pretendiente a familiar del Santo Oficio en Andújar ${ }^{44}$. Del mismo modo, su mujer, María Antonia Camacho, cumplía también con las condiciones requeridas, incluida la de limpieza de sangre. Era hija de Jacinto Camacho, señor de la villa de Herdales del Río, caballero de la Orden de Santiago y teniente coronel del Regimiento Provincial de Bujalance, y de doña

quisición, leg. 3723, exp. 7; proceso de fe seguido por el Tribunal de Córdoba entre 1771 y 1772 contra Cristina Bavianin por bigamia (AHN, Inquisición, leg. 1850, exp. 14; proceso de fe iniciado por el Tribunal de Córdoba en 1775 contra Juan Caamaño, secretario de la Superintendencia, por proposiciones. AHN, Inquisición, leg. 3730 , exp. 42.

39 Hamer Flores, A.: "La presencia protestante en las Nuevas Poblaciones de Carlos III", Arte, Arqueología e Historia, 12 (2005), pp. 141-143.

40 Défourneaux, op. cit. (nota 3), pp. 330 y 340.

41 Pérez-Schmid Fernández, F.J.: "Un alguacil mayor del tribunal de la Inquisición para La Carolina", Boletín del Centro de Estudios Neopoblacionales, 8 (2016), pp. 54-55.

42 Cerrillo Cruz, G.: “Alguaciles mayores de la Inquisición. Alguaciles Mayores del Tribunal de Sevilla en el siglo XVIII”, Revista de la Inquisición, 6 (1997), pp. 175-176.

43 Nombramiento, por parte de los inquisidores de los reinos de Córdoba y Jaén, Adelantamiento de Cazorla, Abadía de Alcalá la Real, ciudad de Écija, villa de Estepa y su partido, de Alonso Mesía Valdivia como "alguacil mayor de este Santo Oficio en la villa de La Carolina”, 26 de abril de 1777, Archivo Histórico Municipal de La Carolina (AHMLC), Expedientes de Procedimientos Civiles, 2.3.8. Años 1768-1776.

44 Información genealógica de Alonso Mesía y Valdivia, AHN, Inquisición, leg. 5183, exp.1. 
María Hipólita Camacho Pedrajas. Su hermano Antonio Camacho sucedió a su padre en el mencionado señorío y fue nombrado primer conde de Robledo de Cardeña ${ }^{45}$.

Las lagunas documentales existentes tanto en los fondos inquisitoriales como en los locales nos impiden conocer la frecuencia con la que se siguieron haciendo este tipo de designaciones para las nuevas colonias, aunque el hecho de que el obispo de Jaén Rubín de Ceballos ocupase el cargo de inquisidor general entre 1784 y 1792 hace muy factible que esta práctica se consolidase. Es conocida su férrea defensa de la ortodoxia católica, hasta el punto de haber encargado, motu propio, la elaboración de un nuevo Índice inquisitorial, publicado en 1792, a pesar de la oposición del propio Consejo de la Suprema Inquisición ${ }^{46}$. Una hipótesis reforzada por la existencia de otro nombramiento como comisario del Santo Oficio de la Inquisición de Córdoba en la capital de las colonias de Sierra Morena, realizado el 24 de septiembre de 1806, a favor Sebastián Jacinto García Barragán, el cual desempeñaba entonces su ministerio en La Carolina ${ }^{47}$.

\section{Combatiendo una "religiosidad ilustrada"}

Los años inmediatamente posteriores a 1776, como ya hemos esbozado, implicaron para las Nuevas Poblaciones de Sierra Morena y Andalucía la aplicación de numerosas iniciativas, así como el desarrollo autónomo de prácticas religiosas al no encontrar limitaciones, las cuales permitieron eliminar cualquier rastro del modelo de religiosidad que Pablo de Olavide había tratado de fomentar durante casi una década. En un espacio que ofrecería menos resistencia que Madrid y, sobre todo, Sevilla, este influyó en las actividades de la Iglesia y solo consintió los rasgos de religiosidad popular que consideraba más adecuados. Hizo todo lo posible para que las iglesias estuvieran dedicadas a la Inmaculada Concepción, impidiendo que existiera más de un altar o dos en cada templo y, por tanto, evitando el culto a los santos. Unas decisiones que causaron algunas protestas, aunque siempre tímidas, de los colonos y de los eclesiásticos. Del mismo modo, no dudó en interferir en los oficios religiosos dando órdenes acerca de la forma de vestir de las mujeres, prohibiendo ropas que cubriesen sus cabezas y hombros, e incluso impulsando la introducción, durante la misa, de una serie de cánticos para los que él mismo compuso varias canciones. Aún más, por si todavía quedaba algún resquicio para evitar que los detractores de sus ideas considerasen, como de hecho así ocurrió, el elevar a instancias superiores acusaciones y denuncias contra el limeño, su radical oposición a que se desarrollasen actividades religiosas en el espacio público (como procesiones o el rosario cantado) y a que existiesen cofradías religiosas, lo hizo desaparecer por completo. El fraile capuchino alemán fray Romualdo de Friburgo, destinado para la asistencia espiritual de los colonos alemanes de La Carolina,

45 Ramos, A.: Descripción genealógica de la casa de Aguayo, y líneas que se derivan de ella desde que se conquistó Andalucia por el Santo Rey D. Fernando III hasta el presente, Málaga, Impresor de esta M. I. Ciudad, de la dignidad Episcopal y de la Santa Iglesia Catedral, 1781, p. 149.

46 Larriba, E.: El público de la prensa en España a finales del siglo XVIII (1781-1808), Zaragoza, Prensas de la Universidad de Zaragoza, 2013, p. 133.

47 Traslado realizado en La Carolina, el 4 de octubre de 1806, del título de comisario del Santo Oficio de la Inquisición de Córdoba realizado a favor del presbítero Sebastián Jacinto García Barragán, AHMLC, Nombramientos de cargos, 1.1.2.1. Años 1792-1830. 
no dudó en liderar una verdadera campaña de delaciones contra el limeño ante la Inquisición.

Tras su marcha de las nuevas colonias, los recintos sagrados, caracterizados por una enorme austeridad y en los que habitualmente se podían encontrar solo uno o dos altares, ocupados preferentemente por la imagen de la Inmaculada Concepción, empezaron a llenarse de nuevos altares e imaginería variada; una religiosidad popular en la que las muestras públicas de fe habían sido escasas encuentra ahora nuevas vías de expresión a través de las cofradías y hermandades, así como por la creación de vía crucis a iniciativa de eclesiásticos como fray Diego José de Cádiz; y, por último, los cultos y devociones de los colonos, desarrollados discretamente durante años, se plasmaron abiertamente en su día a día y en sus últimas voluntades.

\section{De las iglesias vacías a la profusión de altares y ornamentos}

Durante los años que Pablo de Olavide estuvo al frente de la Superintendencia parece ser que las parroquias y capillas de las nuevas colonias solo se dotaron con nuevas imágenes de la Purísima. Un hecho que queda patente cuando el capellán mayor de Sierra Morena, Lanes y Duval, nos indica cómo en 1770 llegaron las imágenes de la Inmaculada a la nueva iglesia de La Carolina (de bulto redondo) y a las iglesias de Navas de Tolosa, Montizón o Carboneros (en pintura) ${ }^{48}$. En consecuencia, este fue el único culto implantado directamente por la Superintendencia en esta primera época, lo cual se reflejó en la dedicación de prácticamente todas las nuevas iglesias parroquiales a dicha advocación. Ciertamente, como Olavide indicó en 1776 al inquisidor general Felipe Beltrán, no se suprimió el culto de las imágenes previas existentes en los templos refundados como parroquias (como en Santa Elena ${ }^{49}$, Zocueca y Venta de los Santos), incluso algunas aumentaron su número gracias a las incluidas en los retablos de las casas jesuitas (en La Luisiana, Fuente Palmera y San Sebastián de los Ballesteros $)^{50}$, pero todas ellas pasaron claramente a un segundo plano.

Ahora bien, tras su encarcelamiento, los párrocos no esperaron demasiado para solicitar o incluso promover la creación de nuevos altares en sus templos. El capellán mayor de La Carolina reiteró en febrero de 1777 su petición de dos efigies para ubicarlas en las hornacinas laterales de esta iglesia, que permanecían vacías ${ }^{51}$. Al parecer, según indicaba el propio superintendente el año anterior, se había considerado colocar en ellos sendas efigies de San Pedro y San Pablo ${ }^{52}$; aunque lo cierto es que las gestiones, un año después, no habían avanzado. En octubre de 1777, Ondeano indicaba al secretario de Hacienda que el obispo de Jaén había decidido que fueran

48 Biblioteca de Castilla-La Mancha (BCLM), ms. 9, pp. 82-83, 87-88, 104-105 y 106-107. Pérez Fernández, F.J.: Colonos y propietarios de las Nuevas Poblaciones de Sierra Morena durante la Edad Moderna, Jaén, Universidad de Jaén, 2019, pp. 243, 247, 252 y 255.

49 En la ermita de Santa Elena existía una imagen de la Inmaculada, situada encima del Sagrario, con anterioridad a la fundación de la nueva población (BCLM, ms. 9, pp. 89-91).

50 Carta de Pablo de Olavide al inquisidor general, Madrid, 19 de marzo de 1776. AHN, Inquisición, leg. 3609, s.f.; transcrito en Sánchez-Batalla Martínez, C.: La Carolina en el entorno de sus colonias gemelas y antiguas poblaciones de Sierra Morena. Prehistoria a 1835, Jaén, Caja Rural de Jaén, 2000, II, pp. 430-443.

51 Carta de Juan Lanes y Duval a Miguel de Ondeano, 9 de febrero de 1777, y carta de Miguel de Ondeano a Juan Lanes y Duval, 15 de febrero de 1777, AGS, Secretaría y Superintendencia de Hacienda, leg. 499, docs. 62 y 64.

52 Carta de Pablo de Olavide al inquisidor general, Madrid, 19 de marzo de 1776, AHN, Inquisición, leg. 3609, s.f. 
dos imágenes de cuerpo entero pero que, aunque Olavide ya había pensado los santos que colocarían, quizá convendría que el rey se pronunciase acerca de sus preferencias. La respuesta del monarca se limitó a dejar este asunto en manos del obispo ${ }^{53}$. No obstante, esta cuestión se retrasó varios años. Solo a comienzos de 1783 se dictó la real orden por la que el rey, accediendo a la propuesta del obispo Rubín de Ceballos, que había visitado la parroquia en agosto del año anterior, ordenaba a Francisco Sabatini que dispusiera la ejecución de un San Carlos Borromeo y de un San Juan de la Cruz para ubicarlos en esos altares ${ }^{54}$. Ambos pasaban a compartir compatronazgo con la Purísima, el primero en la iglesia parroquial de La Carolina en homenaje al rey y el segundo en su feligresía por haber sido aclamado "por la devoción de los fieles de aquella capital y su comprensión" "55. Desconocemos cuánto se dilató la realización de estas imágenes, a las que se sumó en marzo de 1784 otra petición de una Virgen de los Dolores para la misma parroquia, pero en febrero del año siguiente se dice de ellas que ya estaban instaladas en el templo de la capital de las colonias de Sierra Morena $^{56}$.

La llegada de un San José y de un San Antonio de Padua a la parroquia de La Carolina en 1778, compradas por la Superintendencia mientras Olavide permanecía encarcelado, así como la colocación para su culto de una primera imagen de la Dolorosa, parecen evidenciar no solo un deseo de minimizar las acusaciones contra el superintendente ${ }^{57}$ sino también una estrategia de aquellos que habían sido sus más estrechos colaboradores para desmarcarse de cualquier sospecha que pudiera girar en torno a ellos. El carácter más popular de estas imágenes, sin duda, aseguraba que los fieles estuvieran satisfechos con su ubicación en la iglesia. El superintendente se había opuesto en sus años de gobierno a estos cultos más populares, argumentando que solo servían para distraer a los colonos de su trabajo, tal y como lo demuestra su rechazo a que estos, especialmente los de origen valenciano, pudieran visitar en la iglesia a San Antonio de Padua los martes y a San Francisco de Paula los viernes para rezar el rosario y encender velas, así como a su petición de costear una fiesta para San Antonio ${ }^{58}$. En los años siguientes, en cambio, el capellán mayor Lanes y Duval decidió apoyar estos cultos, adquiriendo una imagen de San Antonio para La Carolina, como vimos con anterioridad, y algunas otras atendiendo a las peticiones de los vecinos de Navas de Tolosa y Santa Elena para colocarlas en sus parroquias ${ }^{59}$. Tanto éxito tuvieron estas devociones que San Antonio de Padua llegó a tener culto e

53 Carta de Miguel de Ondeano a Miguel de Múzquiz, La Carolina, 17 de octubre de 1777, AGS, Secretaría y Superintendencia de Hacienda, leg. 499, docs. 211 y 212.

54 Carta de Miguel de Ondeano a Miguel de Múzquiz, La Carolina, 28 de febrero de 1783, AGS, Secretaría y Superintendencia de Hacienda, leg. 500, doc. 14.

55 Carta de Miguel de Ondeano a Miguel de Múzquiz, La Carolina, 29 de diciembre de 1782, AGS, Secretaría y Superintendencia de Hacienda, leg. 500, doc. 82.

56 Carta de Francisco Sabatini al conde de Floridablanca, Madrid, 4 de febrero de 1785, AGS, Secretaría y Superintendencia de Hacienda, leg. 500, doc. 184.

57 En este mismo sentido, sabemos que en 1776 Ondeano y el capellán mayor Lanes y Duval procedieron a embargar los bienes de fray Romualdo de Friburgo, principal instigador de las acusaciones contra Olavide, pero esta medida, lejos de beneficiar al superintendente, acabó por complicar todavía más su delicada situación. Gómez Urdáñez, J.L.: “Con la venia de Carlos III. El castigo 'ejemplar' de Olavide, consecuencia de la venganza de Grimaldi contra el conde de Aranda”, Vegueta: Anuario de la Facultad de Geografia e Historia, 15 (2015), p. 395.

58 Declaración de José Rodríguez, 1776, AHN, Inquisición, 1866, pieza 2, testigo 74.

59 BCLM, ms. 9, pp. 82, 89 y 92. 
imagen en casi todas las iglesias de las colonias de Sierra Morena, y hasta fiestas en su honor como las constatadas en Navas de Tolosa en $1856^{60}$.

Por otro lado, la llegada desde Madrid, a comienzos de los años ochenta, de la segunda Dolorosa, cuya realización mencionábamos anteriormente, hizo posible el que la calidad artística de las imágenes colocadas en los altares de la iglesia de La Carolina se incrementase, adaptándose así a las mejoras introducidas gracias a diversas obras desarrolladas en el interior del recinto. En este sentido, según nos dice Ondeano, la nueva talla se ubicó, con el fin de incentivar "la devoción de los fieles, en una capilla que se ha construido con este fin" ${ }^{61}$. Como contrapartida, las imágenes que ya no tenían cabida en la iglesia de la capital se destinaron a otras. Este fue el caso, precisamente, de la primera Virgen de los Dolores, que pasó a la iglesia de Navas de Tolosa, donde hizo posible que la devoción popular de esta colonia, centrada hasta entonces en la Inmaculada por ser la única existente en ella, se enriqueciera con el culto en torno a esa Dolorosa ${ }^{62}$.

El resto de las iglesias de las colonias de Sierra Morena también verían incrementados el número de altares y cultos, aprovechando la necesidad que algunas iglesias, como la de Navas de Tolosa, tuvieron de ser reedificadas desde los cimientos. Por ejemplo, en Aldeaquemada se confirma ya en 1780 la existencia de dos imágenes aparte de la de la Inmaculada. No podemos asegurar si ambas eran de bulto redondo, pero en ese año la colona Catalina Font dejaba estipulado en su testamento que se comprasen doce velas para colocarlas alrededor de su cadáver, dejando todo el sobrante de dicha cera para que se ubicase ante Nuestra Señora del Rosario, ante Nuestra Señora de los Dolores y ante la Purísima Concepción de esa parroquia ${ }^{63}$. Igualmente, el colono Francisco Calabria reafirma la existencia entonces de Nuestra Señora de los Dolores al disponer en sus últimas voluntades, también en ese año, que se colocase ante ella el sobrante de una libra de cera ${ }^{64}$.

En las Nuevas Poblaciones de Andalucía la situación fue muy similar. En la parroquia de su capital existían, a comienzos de marzo de 1787, un total de seis altares, con lo que su número se había incrementado en cuatro tras la marcha de Olavide ${ }^{65}$. Junto al altar mayor, dedicado a la Inmaculada Concepción ${ }^{66}$, y el dedicado al Sagrario, encontramos ahora uno con la Virgen del Rosario ${ }^{67}$, otro en el que se veneraba a San José, otro que albergaba una imagen de San Antonio de Padua y otro último en el

60 Sánchez-Batalla Martínez, C.: La Carolina: historia de la segunda mitad del siglo XIX, Jaén, Caja Rural de Jaén, 2010, p. 377.

61 Carta de Miguel de Ondeano a Miguel de Múzquiz, La Carolina, 29 de diciembre de 1782, AGS, Secretaría y Superintendencia de Hacienda, leg. 500, doc. 82.

62 Palacio Atard, op. cit. (nota 14), p. 58.

63 Testamento de Catalina Font, Aldeaquemada, 15 de enero de 1780, AHMLC, Testamentos, 7.1. Años 17701785.

64 Testamento de Francisco Calabria, Aldeaquemada, 24 de marzo de 1780, AHMLC, Testamentos, 7.1. Años $1770-1785$.

65 Biblioteca Nacional de España (BNE), ms. 7294, f. 398r y v.

66 A este altar se habían incorporado las imágenes de San Juan Bautista y San Cayetano.

67 Para colocar esta imagen se aprovechó el altar del Sagrario para dar lugar a un altar doble, quedando situado el referido Sagrario bajo la peana de la Virgen. Esta talla era la segunda que con esta advocación que se ubicaba en la iglesia de La Carlota. La primera, que solo estuvo unos pocos años, era de candelero y fue adquirida en septiembre de 1777 al artífice astigitano Juan Bautista Finares. En Archivo Parroquial de La Carlota, Córdoba (APLC), Cofradías, caja 1, Cuentas de la cofradía de Nuestra Señora del Rosario de La Carlota. 
que estaba colocado un San Francisco Javier. Es más, en agosto de ese mismo año ${ }^{68}$ nos consta que una imagen de María Santísima de los Dolores también disponía de un altar en el templo ${ }^{69}$. En la colonia de San Sebastián de los Ballesteros se hizo un retablo para el cuadro de San Sebastián con su repisa por valor de 287 reales y 17 maravedíes en $1779^{70}$ y se incluyó otro nuevo altar en $1780^{71}$. Ambos, muy probablemente elaborados por José Piñas ${ }^{72}$. Animados por el capellán José López Tinoco, un grupo de colonos “de tres naciones, que son alemanes, franceses y españoles”, recaudaron limosna para adquirir por 150 reales, el 10 de octubre de 1780, una imagen de talla de San José propiedad de un matrimonio vecino de la localidad ${ }^{73}$ y para sufragar la construcción del nicho que la albergaría en el lado de la Epístola, al igual que para costear la compra y traslado desde la catedral de Córdoba de un ara para decir misa. El mencionado sacerdote se encargó de poner la primera piedra en ese altar y de decir una misa en este, a la que le siguieron otras muchas rezadas. Unos meses más tarde se mejoró con fondos de la Real Hacienda, con lo que se pudieron cantar en él las primeras Vísperas que se cantaron en esa iglesia ${ }^{74}$. Un impulso que no se frenó en los años siguientes, como lo demuestra la existencia, en agosto de 1786, de un total de siete altares en esta pequeña iglesia ${ }^{75}$. Carecemos de información acerca de lo sucedido en las parroquias de Fuente Palmera y La Luisiana, pero es muy probable que siguieran la misma dinámica.

68 Testamento del capellán mayor y vicario Pedro Cabello del Pino, otorgado el 17 de agosto de 1787. Archivo Notarial de Posadas, Córdoba (ANPO), La Carlota, Escribano Juan Vázquez, prot. 886, año 1787, s.f.. En este documento, el eclesiástico lega 40 reales a la Virgen de los Dolores, a la Virgen del Rosario y a San José "para lo que más falta haga en sus altares".

69 Esta talla de candelero está ubicada actualmente en el altar que ocupaba San Francisco Javier en marzo de 1787, por lo que es probable que al incorporar al templo a la Virgen de los Dolores se trasladase al santo jesuita a otro altar o a una peana (dadas sus reducidas dimensiones). Avalan esta hipótesis el hecho de que todos los documentos históricos siempre localizan a la Virgen en ese altar de la nave del Evangelio y el que la talla de San Francisco Javier esté localizada, ya desde la primera mitad del siglo XIX, en la nave de la Epístola.

70 Nieto Cumplido, M.: "La Iglesia en las Nuevas Poblaciones de Andalucía (1767-1835)”, Boletín de la Real Academia de Córdoba de Ciencias, Bellas Letras y Nobles Artes, 88 (1968), p. 53. Como era de esperar, los colonos incluyeron desde muy pronto este altar en sus peticiones testamentarias. Por ejemplo, Sebastián Mayer dispuso en septiembre de 1781 que todas las misas que se dijesen por su alma e intención se oficiaran en el altar de San Sebastián. ANPO, San Sebastián de los Ballesteros, Escribano Pablo Gómez, prot. 957, año 1781, s.f..

71 Aunque esta iglesia había heredado de la capilla de la antigua hacienda jesuítica un cuadro que representaba el martirio de San Sebastián, que todavía es posible contemplar en ella, todo apunta a que, si llegó a estar colgado en estos primeros años, ese lugar no recibió la consideración de altar.

72 Cuentas del culto de las ánimas en San Sebastián de los Ballesteros entre julio de 1777 y agosto de 1780, APLC, Cofradias, caja 1 .

73 Esta imagen de talla del patriarca San José con el niño en brazos, de una vara de alto, fue donada -a cambio del donativo de 150 reales- por Francisco Javier Márquez y su mujer María Marín, que la había heredado de sus padres, a la iglesia de San Sebastián de los Ballesteros; elevándose dicha donación a escritura pública el 10 de abril de 1781. ANPO, San Sebastián de los Ballesteros, Escribano Francisco Javier Márquez, prot. 957, año 1781, s.f..

74 ANPO, San Sebastián de los Ballesteros, Escribano Pablo Gómez, prot. 957, año 1780, s.f. El capellán José López Tinoco solicitó la protocolización en el oficio de escrituras públicas del fiel de fechos de la colonia del recibo de compra de la imagen, en el que incluyó una breve relación de todo lo ocurrido hasta 19 de noviembre de 1780 .

75 Testamento otorgado el 25 de agosto de 1786, en San Sebastián de los Ballesteros, por el colono alemán Melchor Herman. ANPO, San Sebastián de los Ballesteros, Escribano Pablo Gómez, prot. 957, año 1786, s.f.. 


\section{Las pláticas e iniciativas de fray Diego José de Cádiz}

Una de las respuestas más claras, a la par que virulenta, a las reformas religiosas promovidas por Pablo de Olavide en las Nuevas Poblaciones fue la protagonizada por el capuchino fray Diego José de Cádiz. Perteneciente a los frailes capuchinos menores, destacó por ser uno de los que más se centró en las llamadas misiones populares, que tenían como objeto, según palabras del propio fraile, el atender a "la gravísima necesidad en que se hayan los pueblos de aprender esta doctrina y de renovar la memoria de estas verdades" por "el estado de la extraordinaria relajación de costumbres que se hayan, y de la desmedida, increíble y culpable ignorancia en que nos vemos"76.

Los frailes capuchinos predicaban en fiestas y solemnidades $\mathrm{y}$, sobre todo, en misiones parroquiales donde, a causa de su austeridad, pobreza y fervor, gozaban de gran aceptación popular. Hablaban de forma sencilla y lineal de los vicios y virtudes siguiendo el ejemplo de San Francisco de Asís. La misión de fray Diego en el Obispado de Jaén tuvo, pues, los rasgos característicos de este tipo de acciones: un pequeño grupo de sacerdotes acudía varios días a una localidad dentro de una ruta previamente establecida en una diócesis donde llevaban a cabo un acelerado programa de activismo espiritual. Durante las visitas desarrollaban varios sermones vibrantes, procesiones, confesiones y comuniones masivas, mortificación de la carne mediante ayunos o disciplinas, explicaciones de la doctrina a escolares e iletrados, actos de devoción a los santos o vírgenes de culto local y reuniones con autoridades, párrocos y fuerzas vivas. Además, los misioneros incitaban decididamente un estado de emergencia espiritual y moralidad extrema, arreglando las desavenencias entre vecinos, casando a las parejas amancebadas, cerrando teatros y lugares de vicio y convirtiendo o reconviniendo a notorios impíos ${ }^{77}$.

Con el respaldo del obispado y el visto bueno del subdelegado Miguel de Ondeano, el capuchino llegó a La Carolina en febrero de 1782. Durante dos días y medio, auxiliado por el vicario y capellán mayor Lanes y Duval ${ }^{78}$, por el vicario de Arjona y varios sacerdotes más, el religioso no dudó en cuestionar y atacar al cesado superintendente Pablo de Olavide por sus disposiciones en materia de culto que incluso "daba golpe a los prudentes y juiciosos" por su gobierno contrario a la fe. En palabras de fray Diego: "me di por entendido contra los errores de su poblador Olavide, sin nombrarlo por su nombre, sino solamente vuestro poblador, les exhorté a detestar los errores en fe y costumbres que él les había inspirado, etc.". Además, pudo comprobar que "en todo el pueblo no se hallaba una cruz por las calles, plazas, ni campo", por lo que acordó con el subdelegado que se colocasen cruces en sitios públicos y realizó varías pláticas en el balcón del palacio y la plaza donde había residido

76 Tomado del prólogo de las obras homiléticas de fray Miguel de Santander. Melgares Raya, J.: "Fray Diego José de Cádiz (1743-1801)”, Boletín del Instituto de Estudios Giennenses, 153/2 (1994), p. 1032.

77 Durán López, F.: "Las artes de un predicador en guerra con las Luces, teoría y práctica de la oratoria sacra según el epistolario de Fray Diego José de Cádiz", Dicenda. Estudios de lengua y literatura españolas, 32 (2014), p. 54.

78 Biblioteca de la Real Academia Española (BRAE), RM-6893, pp. 426-427. Dentro de la biblioteca del que fuera capellán mayor de Sierra Morena, Juan Lanes y Duval, encontramos una nutrida representación de obras de fray Diego José de Cádiz en un listado elaborado en torno a 1791. Unos diez tomos donde se incluían el Discurso latino a la Universidad de Baeza, oraciones fúnebres, sermones, panegíricos, etc.; lo cual parece indicar un alto interés de Lanes y Duval por la obra de este capuchino. 
Olavide, con la carga simbólica que esto implicaba ${ }^{79}$. También impulsó la primera salida de un Rosario por las calles de la localidad, realizando junto con los vicarios un triunfo de la Santa Cruz, colocando finalmente cruces en plazas y sitios públicos de La Carolina y pidiendo a los párrocos del resto de colonias de Sierra Morena que también pusieran cruces y vía-sacra en cada una de ellas ${ }^{80}$. Así pues, la visita de fray Diego, tal y como confirma su propio testimonio, se centró de manera fundamental en combatir las reformas que había llevado a cabo Olavide durante su etapa de gobierno, contando para ello con el apoyo del obispado, del capellán mayor de Sierra Morena y con el subdelegado de esas colonias.

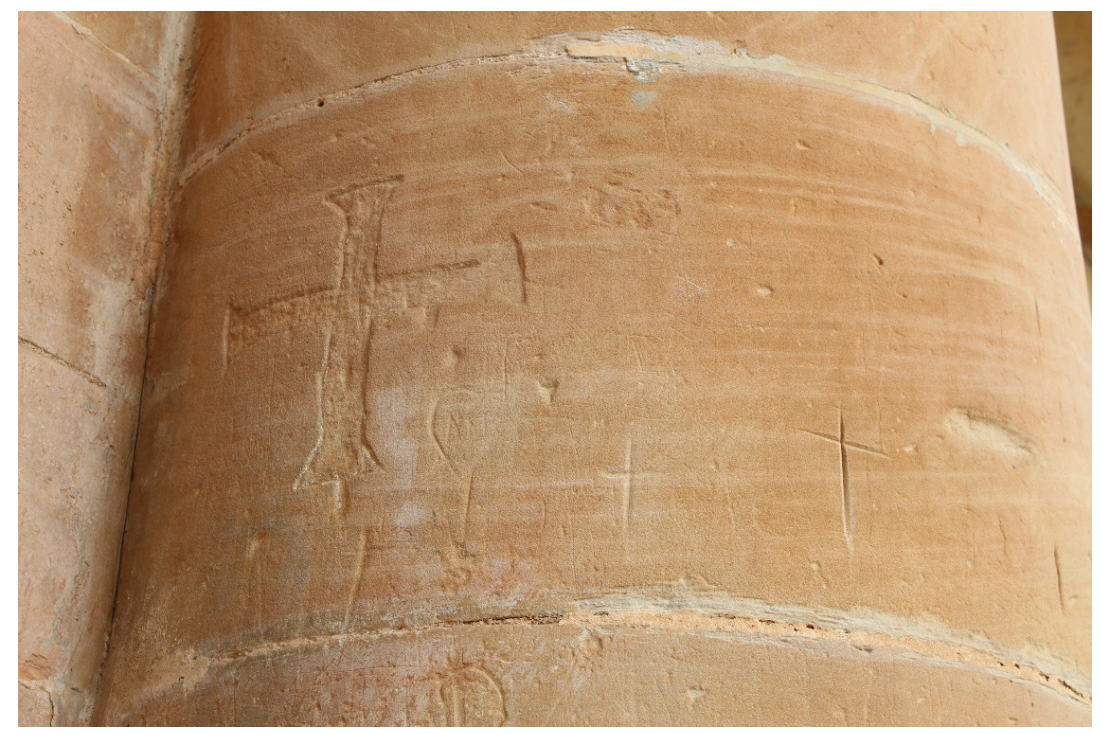

Fig. 1. Detalle de cruces grabadas en la fachada principal del Palacio de la Superintendencia de La Carolina, donde residió Pablo de Olavide. Fotografía de los autores, 2020.

\section{Más allá de la Inmaculada Concepción: los colonos manifiestan su fe}

La devoción por la Inmaculada Concepción, y su defensa ante los que se oponían a ella, fue uno de los rasgos que caracterizó a la Corona y a la Iglesia española durante toda la Edad Moderna. El origen de este fervor se retrotrae hasta la Edad Media, cuando no pocos soberanos mostraron su apoyo a la pureza de la concepción de la Virgen. En este sentido, Carlos III no fue una excepción, más bien al contrario, demostró una intensa vinculación con esta advocación mariana; tanto es así que decidió declararla patrona de la monarquía española, después de que las Cortes también lo

\footnotetext{
Aunque no disponemos de evidencias documentales que permitan verificarlo, resulta muy significativo y sugerente que la fachada de piedra de este palacio donde residió Pablo de Olavide sea la única de un edificio público de La Carolina de época foral en la que pueden contemplarse numerosos grabados de factura popular representando cruces de diversas tipologías flanqueando la puerta principal de entrada (véase la Fig. 1). Tal vez se buscase con esta acción el bendecir de algún modo el lugar de residencia de alguien sentenciado como hereje formal por la Inquisición.

80 Valenciana, A. de: El director perfecto y el dirigido Santo. Correspondencia epistolar del B. Diego José de Cádiz con el V. P. Maestro Francisco Javier González y viceversa, Sevilla, Imprenta de la Divina Pastora, 1924, pp. 571-573; Pérez Fernández y Hamer Flores, op. cit. (nota 10), p. 674.
} 
hicieran a propuesta suya, y logró que el papa Clemente XIII, por el breve de 8 de noviembre de 1760, confirmase dicho patronato. Incluso puso en marcha en 1771 en su honor la Real y Distinguida Orden de Carlos III ${ }^{81}$.

Esta circunstancia explica que, siendo las Nuevas Poblaciones de Sierra Morena y Andalucía una iniciativa de la monarquía, tanto los miembros de la administración central como los propios individuos que tuvieron la responsabilidad de su puesta en marcha y gobierno no dudaran en situarlas también bajo su patronazgo. La práctica totalidad de las iglesias principales de cada feligresía se dedicaron a la Inmaculada Concepción, cuya imagen ocupaba el altar principal, a veces el único existente; una circunstancia que ha perdurado hasta la actualidad en buena parte de ellas. Pablo de Olavide, que siempre se mostró poco partidario del culto a los santos y de otras prácticas como el rezo del rosario, como evidenciaría su proceso inquisitorial, puso especial énfasis en fomentar entre los colonos esa devoción a la Inmaculada Concepción. Ciertamente, carecemos de datos para poder afirmar si este proceder buscaba sobre todo agradar al monarca o si realmente el limeño también era devoto de ella. Aunque no es una prueba concluyente, consideramos de interés el hecho de que, en junio de 1754, cuando aún no había contraído matrimonio ni desempeñaba ningún cargo cercano a los grandes políticos ilustrados de la corte, entre los escasos objetos de posible temática religiosa que se inventariaron en su domicilio madrileño hubiera una pintura de Nuestra Señora de la Concepción de vara y media de alto y una de ancho ${ }^{82}$.

Por otro lado, como ya hemos tenido ocasión de indicar, el artículo 77 del Fuero de Población prohibía expresamente el establecimiento en las nuevas colonias de conventos, comunidades, hospicios o instituciones similares, con lo que se trataba de evitar que los colonos pudieran gastar con facilidad su dinero en ellos o cederles un porcentaje de sus bienes. Así, la mayor parte de las cantidades invertidas en misas y culto recaería en las iglesias y capillas de las Nuevas Poblaciones, con lo que se facilitaba el sustento de los eclesiásticos y repercutía en una mejora de las actividades de culto realizadas. Una circunstancia que también se dio con las cofradías y hermandades que empezaron a establecerse a partir de 1777, pues sus ingresos contribuyeron a paliar situaciones de necesidad y a incrementar los ingresos y el patrimonio de las parroquias gracias a las misas, las imágenes y los ornamentos que sufragaban ${ }^{83}$.

Todas estas limitaciones, sin embargo, no lograron que los vecinos de las nuevas colonias renunciasen a solicitar misas por descargo de sus almas o de las de sus familiares, aunque las cantidades invertidas fueran superiores a las que Olavide consideraba prudente, así como tampoco a manifestar sus devociones por otras advocaciones y santos. De hecho, esto fue lo habitual en un contexto en el que el culto a la Inmaculada Concepción no dio lugar durante toda la etapa foral a la formación de una agrupación o hermandad en ninguna feligresía. Como suele ser habitual, los testimonios documentales y materiales ${ }^{84}$ vinculados a las actividades devocionales

81 Palacio Atard, V.: Carlos III, el rey de los ilustrados, Barcelona, Ariel, 2006, p. 49. Arteta de Monteseguro, A.: Oración fúnebre que en las solemnes exequias del Sr. Rey don Carlos III, mandada celebrar por la Real Sociedad Aragonesa de Amigos del País en la iglesia de San Carlos Borromeo de la ciudad de Zaragoza el día 31 de enero de 1789, Zaragoza, Imprenta de la viuda de Miedes, 1789, p. 56.

82 AHN, Consejos, leg. 20296, exp. 1.

83 Pérez Fernández y Hamer Flores, op. cit. (nota 10), p. 670.

84 Los testimonios de este tipo, datados de la época que analizamos, que han llegado hasta nuestros días se reducen a una inscripción. En la Aldea de los Ríos, dependiente de Guarromán, se conserva una hornacina vacía encima 
de la población son escasos y, además, buena parte de ellas nunca generaron ningún tipo de registro escrito. Ello dificulta cualquier aproximación que deseemos realizar, por lo que el investigador debe acudir a las pocas fuentes que reflejan parte de esas prácticas. Es más, la ausencia de libros de colecturías y de listados similares para la época analizada en las nuevas colonias hace que tengamos que acudir como única fuente a los testimonios de última voluntad. Aunque no todos los colonos testaron y, de los que sí lo hicieron, muchos testamentos no se han conservado hasta nuestros días, los que hemos podido localizar permiten obtener una visión general acerca de sus principales preocupaciones en materia de fe y de cómo los esfuerzos del superintendente no pudieron impedir que tanto los españoles como extranjeros manifestaran sus devociones por santos, Cristos y Vírgenes de localidades vecinas, especialmente por aquellos que disfrutaban de considerable fama debido a las gracias concedidas.

A partir del análisis de un total de 72 testamentos ${ }^{85}$ del periodo comprendido entre 1769 y 1784, de los que 44 corresponden a las colonias de Sierra Morena $(61,11 \%)$ y los 28 restantes a las de Andalucía (38,89\%), hemos podido obtener algunas conclusiones muy interesantes ${ }^{86}$. En ambos partidos territoriales se constata el deseo de un conjunto nada desdeñable de colonos $(23,61 \%)$ por sufragar misas en conventos o ermitas fuera de la jurisdicción de la Superintendencia. Entre los lugares normalmente cercanos, devociones populares o de los propios lugares de procedencia de los colonos podemos relacionar el Santo Cristo del Valle, Nuestra Señora de la Cabeza, el convento de San Francisco de Linares o el de Santisteban del Puerto, el Cristo de la Misericordia de Miguelturra, la ermita de Nuestra Señora del Campo de Úbeda, el convento de San Antonio de Recoletos de Úbeda, el convento de San Buenaventura de Baeza, la ermita del Llano de Baños o el Cristo del Valle y el Cristo de San Salvador del reino de Valencia para los que testaron en Sierra Morena. En lo que respecta a los colonos de Andalucía, prometían misas a la capilla de Nuestra Señora de la Victoria y la capilla del Tejar, ambas en término de La Rambla, a los conventos de San Francisco y de Santa Ana de Écija, a Nuestro Padre Jesús Nazareno de La Rambla, a San Antonio de Padua en el Espíritu Santo de La Rambla y a Santa Bárbara, al convento de Nuestra Señora de los Ángeles de la orden de San Francisco en

de la puerta de una casa de reciente construcción, reedificada sobre una casa de colonos. Pese a la demolición del inmueble original, dicha hornacina se volvió a ubicar en su emplazamiento original. En el nicho puede verse una inscripción realizada durante el gobierno del intendente Miguel de Ondeano que dice "Año de 1787 / Viva / la Virgen".

85 Al objeto de descargar de notas al pie la presente investigación, indicaremos aquí las referencias archivísticas de estos documentos: Archivo Histórico Provincial de Jaén (AHPJ), Protocolos de La Carolina, Escribanos Manuel Martínez de la Fuente y Lázaro Ribera, prot. 6221; AHPJ, Protocolos de La Carolina, Escribano Francisco Delgado, prot. 6222; AHMLC, Testamentos, 7.1. Años 1770-1785; AHMLC, Inventarios de Bienes, 7.2. Años 1784-1787; AHMLC, Expedientes de Procedimientos Civiles, 2.3.8. Años 1768-1776; ANPO, La Carlota, Escribano Ignacio del Pozo, prot. 889; ANPO, La Carlota, Escribano Juan Vázquez, prot. 886; y ANPO, San Sebastián de los Ballesteros, Escribano Pablo Gómez, prot. 957. Los nombres y apellidos de los individuos de origen extranjero se han transcrito siguiendo la versión hispanizada de las escrituras notariales.

86 El 27,77\% de los testamentos fue otorgado por colonos de origen extranjero, mientras que el 72,23\% restante corresponde a españoles. Un hecho que, entre otros posibles motivos (no pudiendo obviarse la barrera lingüística), estuvo influenciado por el considerable número de españoles que atrajeron las obras y las actividades industriales impulsadas en torno a La Carolina durante su primera década de existencia. Hipótesis que se ve reforzada cuando consideramos por separado cada uno de los partidos territoriales de la Superintendencia: mientras que en las colonias de Sierra Morena las últimas voluntades de colonos extranjeros apenas alcanzan el 20,45\% del total, en las de Andalucía estas se elevan hasta alcanzar el 39,28\%. 
Hornachuelos, al convento de Nuestro Padre Francisco de Córdoba y al convento franciscano de Montilla.

Una práctica a la que no fueron ajenos los colonos con origen extranjero. A modo de ejemplo, el colono saboyano Marcelino Franco, vecino de Santa Elena, mandó en 1774 decir misas al Santo Cristo del Valle, a las Ánimas, a San Bartolomé y entregar una libra de cera a Nuestra Señora de la Cabeza, cerca de Andújar; y el colono alemán Juan Mayer, vecino de San Sebastián de los Ballesteros, solicitaba en 1775 cinco misas tanto en la capilla de La Victoria como en la del Tejar, muy próximas a dicha colonia pero ya dentro de la jurisdicción de La Rambla.

Las solicitudes de misas por el alma del testante, a veces también por las de sus padres y otros familiares, como era habitual en el resto del país, estuvieron muy relacionadas con los bienes libres que estos poseían, ya que los lotes de tierra y las casas de dotación los disfrutaban en régimen de enfiteusis. Se indicaban cantidades no demasiado altas (solo excepcionalmente se superaban las 50 misas) que, de este modo, no comprometían el patrimonio familiar. En lo que sí apreciamos un cambio después de 1776 es en las solicitudes de acompañamiento en el cortejo fúnebre hacia el cementerio. La creación, con aprobación oficial o sin ella, de cofradías y hermandades hizo que los colonos empezasen a consignar desde fechas muy tempranas algunas cantidades, o bienes en especie, para sufragar los gastos derivados de dicha presencia. No faltaron incluso los que ampliaron esas peticiones, tal y como fue el caso del colono alemán Juan Jorge Lieber, avecindado en La Carlota, que dispuso en 1780 que las cofradías del Rosario y de Ánimas Benditas de esa colonia portasen sus estandartes mientras los hermanos caminaran junto a su ataúd.

\section{Conclusiones}

La detención y encarcelamiento a finales de 1776 de Pablo de Olavide por parte del Santo Oficio implicó, como hemos visto, su separación, primero temporal y después de la sentencia condenatoria de 1778 definitiva, del gobierno de las Nuevas Poblaciones de Sierra Morena y Andalucía. Una caída en desgracia que supuso el punto de inflexión clave para que se diera inicio al progresivo abandono de todas las medidas de índole religiosa que el superintendente había tratado de implantar en esa nueva sociedad agraria. Así pues, las cuestiones analizadas en los apartados anteriores han hecho posible, de un lado, el alcanzar satisfactoriamente el objetivo general que nos propusimos y, de otro, validar la hipótesis de que el modelo de religiosidad popular promovido por Olavide dio rápidamente paso a otro similar al existente en cualquier otra localidad del entorno tanto por impulso de las autoridades civiles y eclesiásticas como por la propia demanda en este mismo sentido de la población.

En primer lugar, las autoridades diocesanas, como hemos podido verificar con detalle para el caso de las colonias de Sierra Morena, ejercieron una labor de supervisión y control más intensiva que en los primeros momentos de la colonización. Aspectos vinculados con la moral y la religiosidad sobre los que hasta entonces no se había actuado con contundencia, comenzaron a ser objetivos prioritarios para el clero local bajo la atenta mirada de sus superiores. Aún más, hasta el Santo Oficio procuró tener algún representante dentro de la jurisdicción de las Nuevas Poblaciones.

En cuanto al aspecto y dotación de los recintos sagrados, el deseo del limeño de que predominara la sencillez y no se erigieran más de uno o dos altares en cada 
uno de ellos, dedicados preferentemente a la Inmaculada Concepción, contó con la oposición de autoridades y feligreses. Casi de inmediato, las iglesias comenzaron a llenarse de nuevos altares e imágenes de santos. Asimismo, las manifestaciones de culto, especialmente las realizadas fuera de las iglesias (limitadas antes por el superintendente), vivieron un resurgir con el rezo de rosarios, la organización de cofradías y hermandades y la vuelta de procesiones y rogativas a las calles y plazas. Los sermones pronunciados por fray Diego José de Cádiz, en 1782, desde el balcón del palacio que el propio Olavide había mandado edificar para que le sirviese de residencia en La Carolina, tuvieron un verdadero efecto liberador; sus críticas directas a las iniciativas de aquel confirmaron a los colonos que era posible manifestar su fe libremente en los espacios públicos.

Finalmente, los cultos y devociones populares a santos y distintas advocaciones marianas, contenidos y limitados durante años para dar preferencia a los centrados en la Inmaculada Concepción y el Santísimo Sacramento, se abrieron paso sin dificultad. Tanto españoles como extranjeros pudieron expresar libremente sus preferencias e invertir las cantidades que considerasen convenientes en la salvación de su alma o el cumplimiento de promesas. El clero no se opondría y las autoridades civiles, siempre que no quedasen deudas con la Real Hacienda, tendrían que aceptarlo, aunque fueran conscientes de que su inversión en actividades primarias o secundarias contribuía más a la prosperidad de esa sociedad agraria que el que finalizasen, en gran medida, en manos de un clero que al que ya mantenía esa misma Real Hacienda.

\section{Bibliografía}

Aguilar Piñal, F.: "La reforma universitaria de Olavide", Cuadernos Dieciochistas, 4 (2003), pp. 31-46.

Alcázar Molina, C.: Los hombres del reinado de Carlos III. Pablo de Olavide (el colonizador de Sierra Morena), Madrid, Editorial Voluntad, 1927.

- Las colonias alemanas de Sierra Morena (Notas y documentos pasa su historia), Madrid, Universidad de Murcia, 1930.

Arteta de Monteseguro, A.: Oración fúnebre que en las solemnes exequias del Sr. Rey don Carlos III, mandada celebrar por la Real Sociedad Aragonesa de Amigos del País en la iglesia de San Carlos Borromeo de la ciudad de Zaragoza el día 31 de enero de 1789, Zaragoza, Imprenta de la viuda de Miedes, 1789.

Castellano Castellano, J.L.: "Las nuevas ideas pedagógicas y la reforma de Olavide", Chronica Nova. Revista de Historia Moderna de la Universidad de Granada, 12 (1981), pp. 67-89.

Cerrillo Cruz, G.: "Alguaciles mayores de la Inquisición. Alguaciles Mayores del Tribunal de Sevilla en el siglo XVIII", Revista de la Inquisición, 6 (1997), pp. 163-190.

Défourneaux, M.: Pablo de Olavide ou l'Afrancesado (1725-1803), Paris, Presses Universitaires de France, 1959. Existe edición (México, Editorial Renacimiento, 1965) y reedición (Sevilla, Padilla Libros, 1990) en español de este libro.

Durán López, F.: "Las artes de un predicador en guerra con las Luces, teoría y práctica de la oratoria sacra según el epistolario de Fray Diego José de Cádiz", Dicenda. Estudios de lengua y literatura españolas, 32 (2014), pp. 51-81. 
Fernández García, J.: “Aspectos particulares y decisivos de la Iglesia en las Nuevas Poblaciones”, en Vázquez Lesmes, R. y Villas Tinoco, S. (coords.): Actas del VI Congreso Histórico sobre Nuevas Poblaciones, Córdoba, Junta de Andalucía, 1994, pp. 97-108.

Fernández Sanz, A.: "La reforma universitaria del ilustrado Pablo de Olavide", Anales del Seminario de Historia de la Filosofía, Extra n 1(1996), pp. 327-345.

García Cano, M.I.: "El proceso inquisitorial de Pablo de Olavide en el Siglo de las Luces", Codex. Boletín del Instituto Español de Estudios Histórico-Jurídicos, 8 (2018), pp. 57-92.

Gómez Urdáñez, J.L.: "El caso Olavide: el poder absoluto de Carlos III al descubierto", en Muñoz Machado, S. (ed.): Los grandes procesos de la Historia de España, Barcelona, Crítica, 2002, pp. 308-334.

— "Con la venia de Carlos III. El castigo 'ejemplar' de Olavide, consecuencia de la venganza de Grimaldi contra el conde de Aranda", Vegueta: Anuario de la Facultad de Geografía e Historia, 15 (2015), pp. 373-400.

Hamer Flores, A.: "La presencia protestante en las Nuevas Poblaciones de Carlos III", Arte, Arqueología e Historia, 12 (2005), pp. 140-145.

Hamer Flores, A. y Pérez[-Schmid] Fernández, F. J.: "Visualizando el poder real. Toponimia y heráldica en las Nuevas Poblaciones de Sierra Morena y Andalucía", Investigaciones Históricas. Época Moderna y Contemporánea, 39 (2019), pp. 257-292.

- "Una fe a la luz de la Ilustración. El frustrado modelo de religiosidad de Pablo de Olavide para las Nuevas Poblaciones de Sierra Morena y Andalucía (1767-1776)", Hispania Sacra, 147 (2021), en prensa.

Larriba, E.: El público de la prensa en España a finales del siglo XVIII (1781-1808), Zaragoza, Prensas de la Universidad de Zaragoza, 2013.

Lavalle, J.A.: Don Pablo de Olavide. Apuntes sobre su vida y sus obras, Lima, Imprenta Americana, 1859. Hubo una segunda edición corregida y ampliada en 1885 (Lima, Imprenta del Teatro).

Marchena Fernández, J.: Pablo de Olavide, el espacio de la Ilustración y la reforma universitaria. Vida y obra de un ilustrado americano y español, Sevilla, Universidad Pablo de Olavide, 2000.

Martínez Rojas, F.J.: “Organización eclesiástica y atención pastoral en las Nuevas Poblaciones de Sierra Morena", en F. J. Pérez-Schmid Fernández, F.J. y Rodrigo Sanjuán, P. (coords.): 250 aniversario de la promulgación del Fuero de las Nuevas Poblaciones, Jaén, Fundación Caja Rural de Jaén, 2018, pp. 57-65.

Melgares Raya, J.: "Fray Diego José de Cádiz (1743-1801)”, Boletín del Instituto de Estudios Giennenses, 153/2 (1994), pp. 1031-1040.

Nicás Moreno, A.: Heráldica y genealogía de los obispos de la Diócesis de Jaén, Jaén, Instituto de Estudios Giennenses, 1999.

Nieto Cumplido, M.: "La Iglesia en las Nuevas Poblaciones de Andalucía (1767-1835)", Boletín de la Real Academia de Córdoba de Ciencias, Bellas Letras y Nobles Artes, 88 (1968), pp. 33-92.

Palacio Atard, V.: Las «Nuevas Poblaciones» andaluzas de Carlos III. Los españoles de la ilustración, Córdoba, Monte de Piedad y Caja de Ahorros de Córdoba, 1989.

- Carlos III, el rey de los ilustrados, Barcelona, Ariel, 2006.

Perdices Blas, L.: La agricultura de la segunda mitad del siglo XVIII en la obra y empresa colonizadora de Pablo de Olavide, Madrid, Editorial Complutense, 1988.

— "La agricultura en la empresa colonizadora de Pablo de Olavide", en: Estructuras agrarias y reformismo ilustrado en la España del siglo XVIII, Madrid, Ministerio de Agricultura, Alimentación y Medio Ambiente, 1989, pp. 585-589. 
- Pablo de Olavide (1725-1803). El Ilustrado, Madrid, Editorial Complutense, 1992.

Pérez-Schmid Fernández, F.J.: "Un alguacil mayor del tribunal de la Inquisición para La Carolina”, Boletín del Centro de Estudios Neopoblacionales, 8 (2016), pp. 51-55.

- Historia de la colonia de Miranda del Rey y la aldea de Magaña (1767-2017), Jaén, Ayuntamiento de Santa Elena, 2017.

— "Olavide, del pensamiento teórico al práctico: una aproximación al asentamiento de colonos y a los propietarios en las Nuevas Poblaciones", Tiempos Modernos. Revista Electrónica de Historia Moderna, 37 (2018), pp. 299-319.

- Colonos y propietarios de las Nuevas Poblaciones de Sierra Morena durante la Edad Moderna, Jaén, Universidad de Jaén, 2019. Tesis Doctoral inédita.

Pérez[-Schmid] Fernández, F.J. y Hamer Flores, A.: "Ilustración y religiosidad popular en las Nuevas Poblaciones de Sierra Morena y Andalucía: las cofradías que Olavide no quiso", Vegueta: Anuario de la Facultad de Geografía e Historia, 19 (2019), pp. 667-684.

Pérez[-Schmid] Fernández, F.J. y Hamer Flores, A.: "Reformar las costumbres. Pablo de Olavide y su modelo de ocio para las Nuevas Poblaciones de Sierra Morena y Andalucía (1767-1776)", Cuadernos Dieciochistas, 21 (2020), pp. 519-547.

Ramos, A.: Descripción genealógica de la casa de Aguayo, y líneas que se derivan de ella desde que se conquistó Andalucía por el Santo Rey D. Fernando III hasta el presente, Málaga, Impresor de esta M. I. Ciudad, de la dignidad Episcopal y de la Santa Iglesia Catedral, 1781.

Sánchez-Batalla Martínez, C.: La Carolina en el entorno de sus colonias gemelas y antiguas poblaciones de Sierra Morena. Prehistoria a 1835, Jaén, Caja Rural de Jaén, 1998-2003, 4 vols.

- La Carolina: historia de la segunda mitad del siglo XIX, Jaén, Caja Rural de Jaén, 2010.

Valenciana, A. de: El director perfecto y el dirigido Santo. Correspondencia epistolar del B. Diego José de Cádiz con el V. P. Maestro Francisco Javier González y viceversa, Sevilla, Imprenta de la Divina Pastora, 1924. 